\title{
Shewanella donghaensis sp. nov., a psychrophilic, piezosensitive bacterium producing high levels of polyunsaturated fatty acid, isolated from deep-sea sediments
}

Correspondence Sang-Jin Kim s-jkim@kordi.re.kr

\author{
Sung-Hyun Yang, ${ }^{1}$ Jung-Hyun Lee, ${ }^{1}$ Ji-Sun Ryu, ${ }^{1}$ Chiaki Kato ${ }^{2}$ \\ and Sang-Jin $\mathrm{Kim}^{1}$
}

\author{
${ }^{1}$ Marine Biotechnology Research Centre, Korea Ocean Research \& Development Institute, PO \\ Box 29, Ansan 425-600, Republic of Korea \\ ${ }^{2}$ Research Program for Marine Biology and Ecology, Extremobiosphere Research Center, \\ JAMSTEC, 2-15 Natsushima-cho, Yokosuka 237-0061, Japan
}

\begin{abstract}
A Gram-negative, motile, rod-shaped, psychrophilic bacterium, $\mathrm{LT}_{17}{ }^{\top}$, was isolated from deep-sea sediments (3300 $\mathrm{m}$ depth) of the East Sea (Sea of Japan). Optimal growth of $L T 17^{\top}$ requires the presence of $2.5 \%(\mathrm{w} / \mathrm{v}) \mathrm{NaCl}$, a pH of $7.0-7.5$ and a temperature of $17^{\circ} \mathrm{C}$. The isolate grows optimally under a hydrostatic pressure of $10 \mathrm{MPa}$ and growth is possible between 0.1 and $<30 \mathrm{MPa}$. The novel strain is positive in tests for catalase, oxidase, lipase, $\beta$-glucosidase and gelatinase activities and reduces nitrate to nitrate. The predominant cellular fatty acids are iso-

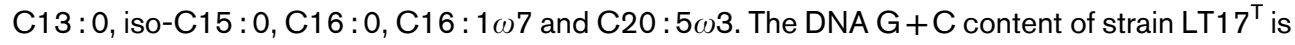
$38.8 \mathrm{~mol} \%$. Phylogenetic analysis of $16 \mathrm{~S}$ rRNA gene sequences places this bacterium in the class Gammaproteobacteria, within the genus Shewanella. The closest relatives of strain $\mathrm{LT}^{\mathrm{T}} 7^{\top}$ are Shewanella japonica (97.8\% gene sequence similarity), Shewanella pacifica ( $97.5 \%)$, Shewanella olleyana (96.8\%), Shewanella frigidimarina (96.5\%) and Shewanella gelidimarina (95.4\%). The DNA-DNA hybridization levels between the novel isolate and its closest known phylogenetic relatives, S. japonica and S. pacifica, are lower than $14 \%$. On the basis of this polyphasic evidence, strain $L T 17^{\top}$ represents a novel species of the genus Shewanella, for which the name Shewanella donghaensis sp. nov. is proposed. The type strain is $\mathrm{LT}_{1} 7^{\top}(=\mathrm{KCTC}$ $10635 \mathrm{BP}^{\top}=\mathrm{JCM} 12524^{\top}$ ).
\end{abstract}

The genus Shewanella was created by the reclassification of two species, Alteromonas putrefaciens and Alteromonas hanedai, that were previously assigned to the genus Alteromonas (MacDonell \& Colwell, 1985). The genus Shewanella is phylogenetically affiliated to the class Gammaproteobacteria and it accommodates Gram-negative, aerobic or facultatively anaerobic and straight or curved rods. Species of the genus Shewanella have been isolated from a variety of sources including clinical samples (Nozue et al., 1992; Brink et al., 1995; Venkateswaran et al., 1999), oilfield fluids (Semple \& Westlake, 1987), aquatic or marine

Abbreviations: EPA, eicosapentaenoic acid; PUFAs, polyunsaturated fatty acids.

The GenBank/EMBL/DDBJ accession number for the 16S rRNA gene sequence of strain $L T 17^{\top}$ is $A Y 326275$.

A graph showing the growth rate of strain $L T 17^{\top}$ under varying pressure conditions and an extended phylogenetic tree based on $16 \mathrm{~S}$ rRNA gene sequences are available as supplementary figures in IJSEM Online. environments (Nealson et al., 1991; Ivanova et al., 2001; Bozal et al., 2002), marine sediments (Myers \& Nealson, 1988) and deep-sea sediments (Nogi et al., 1998). According to various reports, the genus Shewanella is ubiquitous in marine environments including the deep-sea. An interesting feature of species of the genus Shewanella is the ability to produce polyunsaturated fatty acids (PUFAs). Kato \& Nogi (2001) proposed that deep-sea Shewanella species could be taxonomically recognized by two major subgenus branches, one group is characterized by high-pressure cold-adapted species that produce substantial amounts of eicosapentaenoic acid (EPA) and the other group is characterized by mesophilic, pressure-sensitive species that do not produce EPA or produce only scant amounts. Skerratt et al. (2002) and Ivanova et al. (2001, 2004), however, described several species, Shewanella olleyana, Shewanella japonica and Shewanella pacifica, that produce significant levels of PUFAs, such as EPA, at relatively high incubation temperatures $\left(25-30^{\circ} \mathrm{C}\right)$.

In this study, a novel psychrophilic EPA-producing bacterium of the genus Shewanella was isolated from the 
deep-sea and characterized. The bacterium was isolated from sediment samples collected from the East Sea (Sea of Japan; $42^{\circ} 41^{\prime} \mathrm{N} 139^{\circ} 41^{\prime} \mathrm{E}$; $3300 \mathrm{~m}$ depth) by a manned Shinkai 6500 submersible (Yokosuka 01-06 Cruise). Sediment samples were diluted with sterilized seawater and the diluted samples were spread onto marine agar 2216 (MA; Difco) on board just after sampling. Colonies were isolated after incubation at $4{ }^{\circ} \mathrm{C}$ for 2 weeks and one of them, strain $\mathrm{LT} 17^{\mathrm{T}}$, was selected for further study due to its ability to produce EPA and lipase under low temperature conditions.

Unless otherwise stated, morphological and physiological characterizations were performed as described previously (Bae et al., 2005). Cells grown at $10^{\circ} \mathrm{C}$ for 7 days on MA were used to observe morphology and Gram-staining. Growth characteristics under different environmental conditions, including temperature, $\mathrm{pH}, \mathrm{NaCl}$ concentration and hydrostatic pressure, were examined using marine broth 2216 (MB; Difco) as a basal medium using the same methods as described by Seo et al. (2005a).

Strain $\mathrm{LT} 17^{\mathrm{T}}$ was Gram-negative, rod-shaped, motile and approximately $1.0-1.5 \mu \mathrm{m}$ in length and $0.5-0.8 \mu \mathrm{m}$ in width. Colonies formed on MA at $17^{\circ} \mathrm{C}$ after 1 day were orange coloured, circular, opaque, convex with entire margins and $1.5-2 \mathrm{~mm}$ in diameter. The colour changed from orange to slightly pink after 3-4 days incubation. Strain $\mathrm{LT}_{1} 7^{\mathrm{T}}$ grew optimally at $17^{\circ} \mathrm{C}$ and growth was possible between 5 and $20^{\circ} \mathrm{C}$. The growth rate of strain $\mathrm{LT} 17^{\mathrm{T}}$ at $5^{\circ} \mathrm{C}$ was approximately half that of the optimal growth rate. No growth occurred at $22^{\circ} \mathrm{C}$ or higher (Fig. 1). The novel strain grew well within the $\mathrm{pH}$ range 6.5-8.5 and optimally at $\mathrm{pH} 7.0-7.5$. Optimal growth for strain $\mathrm{LT} 17^{\mathrm{T}}$ occurred in the presence of $2.5 \%(\mathrm{w} / \mathrm{v}) \mathrm{NaCl}$; no growth occurred at $\mathrm{NaCl}$ concentrations above $4.5 \%$ or in the absence of $\mathrm{NaCl}$. In addition, strain $\mathrm{LT}_{1} 7^{\mathrm{T}}$ grew optimally at a hydrostatic pressure of $10 \mathrm{MPa}$. However, this strain might be 'piezosensitive' as no growth occurred at $50 \mathrm{MPa}$

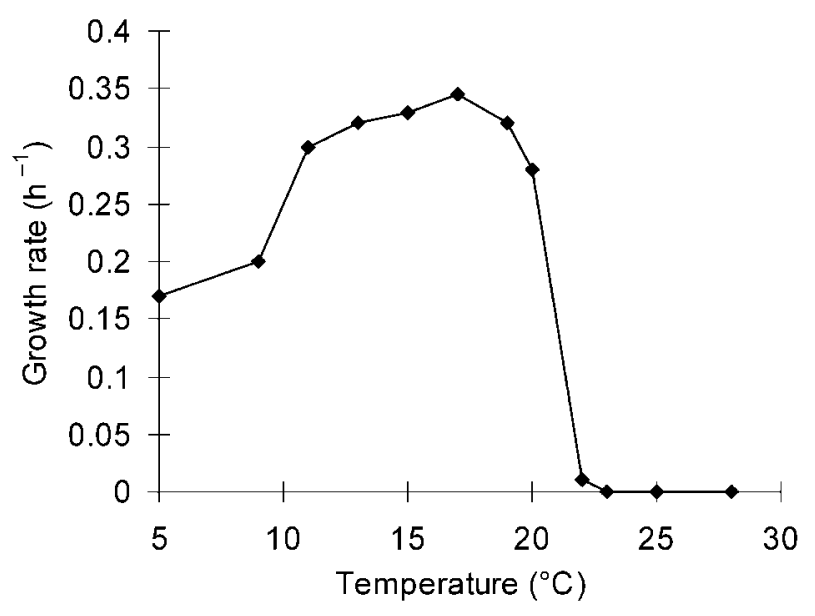

Fig. 1. Temperature-dependent growth rate of strain $L T 17^{\top}$. (see Supplementary Fig. S1 in IJSEM Online). Results of the other phenotypic characterizations are given in the species description and in Table 1.

The 16S rRNA gene was analysed as described by Seo et al. (2005a). The 16S rRNA gene sequence (1539 bp) of strain $\mathrm{LT} 17^{\mathrm{T}}$ was aligned manually with representative sequences of the genus Shewanella and related taxa by using known $16 \mathrm{~S}$ rRNA secondary-structure information. Phylogenetic trees were inferred by the neighbour-joining (Saitou \& Nei, 1987), maximum-likelihood (Felsenstein, 1993) and maximum-parsimony (Fitch, 1971) methods. Evolutionarydistance matrices (for the neighbour-joining method) were generated according to the model of Jukes \& Cantor (1969). The trees were rooted by using Colwellia psychrerythraea (GenBank accession no. AF001375) and Alteromonas macleodii (GenBank accession no. X82145) as an outgroup. The PHYLIP package (Felsenstein, 1993) was used for all analyses. The resultant unrooted tree topology was evaluated by bootstrap analyses (1000 replicates;

Table 1. Physiological characteristics that differentiate strain $\mathrm{LT}_{17}{ }^{\top}$ from related species of the genus Shewanella

Strains: 1, strain $\mathrm{LT} 17^{\mathrm{T}}$; 2, S. olleyana ACAM $644^{\mathrm{T}}$ (data from Skerratt et al., 2002); 3, S. pacifica KMM $3597^{\mathrm{T}}$ (Ivanova et al., 2004); 4, S. japonica KMM $3299^{\mathrm{T}}$ (Ivanova et al., 2001). All species are straight, rod-shaped organisms and are positive in tests for the production of oxidase, catalase, lipase and gelatinase, the reduction of nitrate to nitrite, synthesis of EPA and growth at $10^{\circ} \mathrm{C}$ after $24 \mathrm{~h}$. All species are negative for the utilization of $\mathrm{D}$ mannose and citrate. + , Positive reaction; -, negative reaction; ND, not determined.

\begin{tabular}{|c|c|c|c|c|}
\hline Characteristic & 1 & 2 & 3 & 4 \\
\hline Optimal $\mathrm{pH}$ for growth & $7.0-7.5$ & 7.0 & ND & 7.5 \\
\hline $\begin{array}{l}\text { Optimal temperature for } \\
\text { growth }\left({ }^{\circ} \mathrm{C}\right)\end{array}$ & 17 & $20-22$ & $20-25$ & $20-25$ \\
\hline Growth at $32{ }^{\circ} \mathrm{C}$ & - & + & + & + \\
\hline \multicolumn{5}{|l|}{ Growth in the presence of: } \\
\hline $0 \% \mathrm{NaCl}$ & - & - & - & - \\
\hline $3 \% \mathrm{NaCl}$ & + & + & + & - \\
\hline $6 \% \mathrm{NaCl}$ & - & + & + & - \\
\hline \multicolumn{5}{|l|}{ Production of: } \\
\hline Aesculin & + & + & ND & ND \\
\hline Amylase & - & + & + & + \\
\hline Indole & - & ND & + & ND \\
\hline Urease & - & + & ND & ND \\
\hline \multicolumn{5}{|l|}{ Utilization of: } \\
\hline $\mathrm{N}$-Acetylglucosamine & - & - & - & + \\
\hline Arabinose & - & - & + & ND \\
\hline D-Gluconate & - & + & ND & - \\
\hline D-Glucose & - & - & + & + \\
\hline DL-Malate & - & + & ND & - \\
\hline Maltose & - & - & + & + \\
\hline DNA G $+\mathrm{C}$ content $(\mathrm{mol} \%)$ & 38.8 & 44 & $39.5-40.5$ & $43-44$ \\
\hline
\end{tabular}


Felsenstein, 1985) using the neighbour-joining method. Sequence similarity analysis indicated that the closest relatives of strain $\mathrm{LT}^{\mathrm{T}} 7^{\mathrm{T}}$ were $S$. japonica $(97.8 \%), S$. pacifica (97.5\%), S. olleyana (96.8\%), Shewanella frigidimarina (96.5\%) and Shewanella gelidimarina (95.4\%). Sequence similarities to all other species included in the phylogenetic analyses were $<95.0 \%$ (Fig. 2).

Chemotaxonomic analyses were performed according to a previously described method (Seo et al., 2005a) except that the cells used were cultivated in $\mathrm{MB}$ at $15^{\circ} \mathrm{C}$ for 1 day. Cellular fatty acids of strain $\mathrm{LT} 17^{\mathrm{T}}$ ranged in carbon chain length from $\mathrm{C} 12$ to $\mathrm{C} 20$ and included saturated, unsaturated and iso-branched components (Table 2). The dominant cellular fatty acids were iso-C13:0 (9.8\%), iso-C15:0 (10.4\%), C16: 0 (15.4\%), C16:1 $1 \omega 7$ (18.5\%) and C20: $5 \omega 3$ $(16.2 \%)$; a range similar to that reported for S. olleyana (Skerratt et al., 2002). Of particular note among the fatty acids of strain $\mathrm{LT} 17^{\mathrm{T}}$ was $\mathrm{C} 20: 5 \omega 3$ which is usually found in both psychrophilic and piezophilic marine bacteria (DeLong et al., 1997; Nogi et al., 1998). According to Russell \& Nichols (1999), the progenitor of the genus Shewanella possessed the ability to synthesize PUFAs and this ability has disappeared on several occasions during the divergence of psychrotolerant and/or mesophilic species. Kato \& Nogi (2001) proposed that two major subgenus branches of the

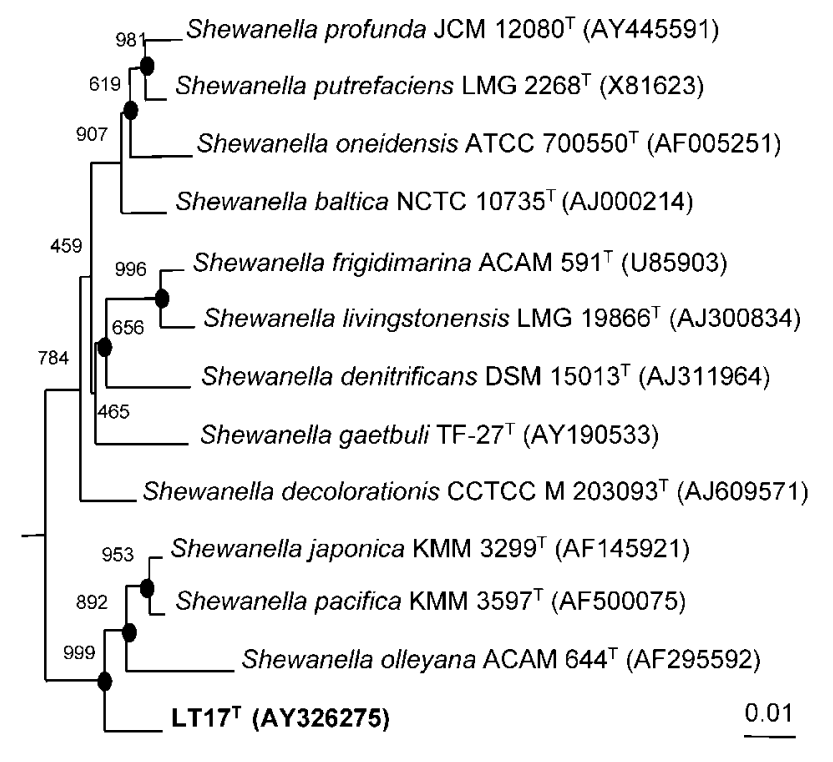

Fig. 2. Neighbour-joining phylogenetic tree showing relationships between strain $\mathrm{LT}_{1} 7^{\top}$ and members of the genus Shewanella based on 16S rRNA gene sequences. Numbers at nodes are levels of bootstrap support, based on neighbourjoining analyses of 1000 resampled datasets. Solid circles indicate that the corresponding nodes (groupings) are also recovered in Fitch-Margoliash, maximum-likelihood and maximumparsimony trees. The full tree from which this figure is taken is available as Supplementary Fig. S2 in IJSEM Online. Bar, 0.01 substitutions per nucleotide position. genus Shewanella should be recognized taxonomically. Group I species were characterized as high-pressure, coldadapted species that produce substantial amounts of EPA (11-16\%), while Group II species included mesophilic, pressure-sensitive species that do not produce or produce only low levels of EPA (3-5\%). However, in the present study, strain $\mathrm{LT}_{1} 7^{\mathrm{T}}$ produces relatively higher concentrations of EPA than Group II species, but does not show any typical characteristics such as piezophily or psychrophily as found in Shewanella Group I species. There are also several contradictory descriptions reported for species of the genus Shewanella such as S. olleyana (Skerratt et al., 2002), S. japonica (Ivanova et al., 2001) and S. pacifica (Ivanova et al., 2004). These findings imply that the presence of EPA in the genus Shewanella is not just associated with psychrophily and piezophily, but is instead a more broadly distributed trait amongst Shewanella species. Production of EPA is an important physiological and descriptive component that allows differentiation between Shewanella species and it may also have an important ecological role, acting as a nutrient source for marine as well as estuarine biota that require essential fatty acids yet are unable to synthesize $\omega 3$ fatty acids de novo (Skerratt et al., 2002).

DNA-DNA hybridization was performed according to the method of Ezaki et al. (1989) using photobiotin-labelled DNA probes. The highest and lowest values in each sample were excluded and the remaining three values were used for calculation of the mean value. DNA-DNA reassociation values between strain $\mathrm{LT} 17^{\mathrm{T}}$ and the type strains of the closely related species $S$. japonica and S. pacifica were lower than $14 \%$. This value is significantly lower than that accepted as the genotypic delineation of a species (Wayne et al., 1987). DNA G $+C$ content was determined by using the HPLC method as described previously by Seo et al. (2005b). The DNA G + C content of the strain $\mathrm{LT}_{17}{ }^{\mathrm{T}}$ was $38.8 \mathrm{~mol} \%$, which is within the accepted range for the genus Shewanella (39-52 mol\%).

\section{Description of Shewanella donghaensis sp. nov.}

Shewanella donghaensis [dong.ha.en'sis. N.L. fem. adj. donghaensis of Donghae, the Korean name for the East Sea (Sea of Japan) from which the strain was isolated].

Cells are rod-shaped, $1.0-1.5 \mu \mathrm{m}$ in length and $0.5-0.8 \mu \mathrm{m}$ in width, single or in chains, motile, Gram-negative and facultatively anaerobic heterotrophs. Colonies are circular, opaque, convex with entire margins and orange coloured. Growth occurs between 5 and $22^{\circ} \mathrm{C}$, with optimum growth at $17^{\circ} \mathrm{C}$. The $\mathrm{pH}$ range for growth is $6.5-8.5$; optimum growth occurs at $\mathrm{pH}$ 7.0-7.5. Growth occurs between 0.5 and $4.0 \%(\mathrm{w} / \mathrm{v}) \mathrm{NaCl}$ and is optimum at $2.5 \%(\mathrm{w} / \mathrm{v}) \mathrm{NaCl}$. The hydrostatic pressure range for growth is between 0.1 and $<30 \mathrm{MPa}$, with the maximum growth rate observed at $10 \mathrm{MPa}$. Catalase- and oxidase-positive. Reduces nitrate to nitrite. Negative in tests for amylase, arginine dihydrolase, urease and $\beta$-galactosidase activities, the production of indole and acidification from glucose. Exhibits gelatinase, 
Table 2. Fatty acid content (\%) of strain $\mathrm{LT}_{1} 7^{\top}$ and related species of the genus Shewanella

Strains: 1, strain $\mathrm{LT}^{\mathrm{T}}$; 2, S. olleyana ACAM $644^{\mathrm{T}}$ (data from Skerratt et al., 2002); 3, S. pacifica KMM 3597 ${ }^{\mathrm{T}}$ (Ivanova et al., 2004); 4, S. japonica KMM 3299 ${ }^{\mathrm{T}}$ (Ivanova et al., 2001); 5, S. gelidimarina (Nichols et al., 1997); 6, S. frigidimarina (Kato \& Nogi, 2001); Values are percentages of total fatty acids. tr, Trace; NA, not available; -, not detected.

\begin{tabular}{|c|c|c|c|c|c|c|}
\hline Fatty acid & 1 & 2 & 3 & 4 & 5 & 6 \\
\hline $13: 0$ & 1.5 & 1.3 & - & 0.6 & 1 & - \\
\hline $15: 0$ & 3.4 & 3.7 & - & 1.1 & 7 & 5 \\
\hline $16: 0$ & 15.4 & 15.2 & 8.9 & 16.6 & 6 & 12 \\
\hline iso- $14: 0$ & 0.2 & 2.5 & - & 0.8 & 1 & - \\
\hline iso- $15: 0$ & 10.4 & 17.8 & 33.9 & 19.6 & 8 & 9 \\
\hline anteiso- $15: 0$ & 0.8 & 2.8 & - & 2.3 & - & - \\
\hline iso- $16: 0$ & 0.4 & 0.5 & - & 0.2 & - & - \\
\hline iso- $17: 0$ & 0.4 & 1.9 & - & 1.6 & $\operatorname{tr}$ & - \\
\hline $20: 5 \omega 3$ & 16.2 & 8.8 & 5.3 & 2.0 & 16 & 3 \\
\hline Optimum growth temperature $\left({ }^{\circ} \mathrm{C}\right)$ & 17 & $20-22$ & $20-25$ & $20-25$ & $15-17$ & $20-22$ \\
\hline Incubation temperature $\left({ }^{\circ} \mathrm{C}\right)$ & 15 & 24 & 28 & 28 & NA & NA \\
\hline
\end{tabular}

aesculin hydrolysis ( $\beta$-glucosidase) and lipase activities. Does not utilize D-glucose, arabinose, D-mannose, Dmannitol, $N$-acetylglucosamine, maltose, D-gluconate, caprate, DL-malate, citrate or phenylacetate as sole carbon sources. Major fatty acids are iso-C13: 0 , iso-C15: $0, \mathrm{C} 16: 0$, $\mathrm{C} 16: 1 \omega 7$ and $\mathrm{C} 20: 5 \omega 3$. The $\mathrm{G}+\mathrm{C}$ content of the DNA is $38.8 \mathrm{~mol} \%$.

The type strain, $\mathrm{LT}^{\mathrm{T}}{ }^{\mathrm{T}}\left(=\mathrm{KCTC} 10635 \mathrm{BP}^{\mathrm{T}}=\mathrm{JCM} 12524^{\mathrm{T}}\right)$, was isolated from deep-sea sediment of the East Sea $(3300 \mathrm{~m}$ depth).

\section{Acknowledgements}

This work was supported by the Marine and Extreme Genome Research Center Program and the Marine Novel Bioactive Development Program, Ministry of Maritime Affairs and Fisheries, Republic of Korea. We are very grateful to the Shinkai 6500 operation team, Mr Imai and co-workers and the captain and crews of the $R / V$ Yokosuka for helping us to collect the deep-sea samples and also to $\mathrm{Mr}$ R. Kasahara for the pressure experiment.

\section{References}

Bae, S. S., Lee, J.-H. \& Kim, S.-J. (2005). Bacillus alveayuensis sp. nov., a thermophilic bacterium isolated from deep-sea sediments of the Ayu Trough. Int J Syst Evol Microbiol 55, 1211-1215.

Bozal, N., Montes, M. J., Tudela, E., Jiménez, F. \& Guinea, J. (2002). Shewanella frigidimarina and Shewanella livingstonensis sp. nov. isolated from Antarctic coastal areas. Int J Syst Evol Microbiol 52, 195-205.

Brink, A. J., van Straten, A. \& van Rensburg, A. J. (1995). Shewanella (Pseudomonas) putrefaciens bacteremia. Clin Infect Dis 20, 1327-1332.

DeLong, E. F., Franks, D. G. \& Yayanos, A. A. (1997). Evolutionary relationships of cultivated psychrophilic and barophilic deep-sea bacteria. Appl Environ Microbiol 63, 2105-2108.

Ezaki, T., Hashimoto, Y. \& Yabuuchi, E. (1989). Fluorometric deoxyribonucleic acid-deoxyribonucleic acid hybridization in microdilution wells as an alternative to membrane filter hybridization in which radioisotopes are used to determine genetic relatedness among bacterial strains. Int J Syst Bacteriol 39, 224-229.

Felsenstein, J. (1985). Confidence limits on phylogenies: an approach using the bootstrap. Evolution 39, 783-791.

Felsenstein, J. (1993). PHYLIP (phylogeny inference package), version 3.5c. Department of Genome Sciences, University of Washington, Seattle, WA, USA.

Fitch, W. M. (1971). Toward defining the course of evolution: minimum change for a specific tree topology. Syst Zool 20, 406-416.

Ivanova, E. P., Sawabe, T., Gorshkova, N. M., Svetashev, V. I., Mikhailov, V. V., Nicolau, D. V. \& Christen, R. (2001). Shewanella japonica sp. nov. Int J Syst Evol Microbiol 51, 1027-1033.

Ivanova, E. P., Gorshkova, N. M., Bowman, J. P., Lysenko, A. M., Zhukova, N. V., Sergeev, A. F., Mikhailov, V. V. \& Nicolau, D. V. (2004). Shewanella pacifica sp. nov., a polyunsaturated fatty acidproducing bacterium isolated from sea water. Int J Syst Evol Microbiol 54, 1083-1087.

Jukes, T. H. \& Cantor, C. R. (1969). Evolution of protein molecules. In Mammalian Protein Metabolism, pp. 21-32. Edited by H. N. Munro. New York: Academic Press. 
Kato, C. \& Nogi, Y. (2001). Correlation between phylogenetic structure and function: examples from deep-sea Shewanella. FEMS Microbiol Ecol 35, 223-230.

MacDonell, M. T. \& Colwell, R. R. (1985). Phylogeny of the Vibrionaceae and recommendation for two new genera, Listonella and Shewanella. Syst Appl Microbiol 6, 171-182.

Myers, C. R. \& Nealson, K. H. (1988). Bacterial manganese reduction and growth with manganese oxide as the sole electron acceptor. Science 240, 1319-1321.

Nealson, K. H., Myers, C. R. \& Wimpee, B. B. (1991). Isolation and identification of manganese reducing bacteria and estimates of microbial manganese $\mathrm{Mn}(\mathrm{IV})$-reducing potential in the Black Sea. Deep Sea Res A 38, Supplement 2, S907-S920.

Nichols, D. S., Nichols, P. D., Russell, N. J., Davies, N. W. \& McMeekin, T. A. (1997). Polyunsaturated fatty acids in the psychrophilic bacterium Shewanella gelidimarina ACAM $456^{\mathrm{T}}$ : molecular species analysis of major phospholipids and biosynthesis of eicosapentaenoic acid. Biochim Biophys Acta 1347, 164-176.

Nogi, Y., Kato, C. \& Horikoshi, K. (1998). Taxonomic studies of deep-sea barophilic Shewanella strains and description of Shewanella violacea sp. nov. Arch Microbiol 170, 331-338.

Nozue, H., Hayashi, T., Hashimoto, Y., Ezaki, T., Hamasaki, K., Ohwada, K. \& Terawaki, Y. (1992). Isolation and characterization of Shewanella alga from human clinical specimens and emendation of the description of S. alga Simidu et al., 1990, 335. Int J Syst Bacteriol 42, 628-634.

Russell, N. J. \& Nichols, D. S. (1999). Polyunsaturated fatty acids in marine bacteria - a dogma rewritten. Microbiology 145, 767-779.
Saitou, N. \& Nei, M. (1987). The neighbor-joining method: a new method for reconstructing phylogenetic trees. Mol Biol Evol 4, 406-425.

Semple, K. M. \& Westlake, D. W. S. (1987). Characterization of iron reducing Alteromonas putrefaciens strains from oil field fluids. Can J Microbiol 35, 925-931.

Seo, H. J., Bae, S. S., Lee, J.-H. \& Kim, S.-J. (2005a). Photobacterium frigidiphilum sp. nov., a psychrophilic, lipolytic bacterium isolated from deep-sea sediments of Edison Seamount. Int J Syst Evol Microbiol 55, 1661-1666.

Seo, H. J., Bae, S. S., Yang, S. H., Lee, J.-H. \& Kim, S.-J. (2005b). Photobacterium aplysiae sp. nov., a lipolytic marine bacterium isolated from eggs of the sea hare Aplysia kurodai. Int J Syst Evol Microbiol 55, 2293-2296.

Skerratt, J. H., Bowman, J. P. \& Nichols, P. D. (2002). Shewanella olleyana sp. nov., a marine species isolated from a temperate estuary which produces high levels of polyunsaturated fatty acids. Int J Syst Evol Microbiol 52, 2101-2106.

Venkateswaran, K., Moser, D. P., Dollhopf, M. E., Lies, D. P., Saffarini, D. A., MacGregor, B. J., Ringelberg, D. B., White, D. C., Nishijima, M. \& other authors (1999). Polyphasic taxonomy of the genus Shewanella and description of Shewanella oneidensis sp. nov. Int J Syst Bacteriol 49, 705-724.

Wayne, L. G., Brenner, D. J., Colwell, R. R., Grimont, P. A. D., Kandler, O., Krichevsky, M. I., Moore, L. H., Moore, W. E. C., Murray, R. G. E. \& other authors (1987). International Committee on Systematic Bacteriology. Report of the ad hoc committee on reconciliation of approaches to bacterial systematics. Int $J$ Syst Bacteriol 37, 463-464. 